\title{
DESKRIPSI PENGETAHUAN DAN SIKAP MAHASISWA TERHADAP HIV DAN AIDS DI AKADEMI KEBIDANAN TAHIRAH AL BAETI BULUKUMBA
}

\author{
Jusni $^{1}$, Rina Mariana ${ }^{1}$, Misriyani ${ }^{2}$, Erniawati ${ }^{1}$ Ika handayani $^{1}$, Nurhayani ${ }^{1}$, Nurhidayat \\ Triananinsi $^{1}$, Mudyawati Kamaruddin ${ }^{1 *}$ \\ ${ }^{1}$ Program Studi Kebidanan, Akademi Kebidanan Tahirah Al Baeti, Bulukumba, Sulawesi Selatan, \\ Indonesia \\ ${ }^{2}$ Fakultas Kedokteran, Universitas Alkhairaat, Jl. Diponegoro Palu 94221, Sulawesi Tengah, Indonesia
}

*Corresponding author: Telp: +628111520603, email: mudya07@gmail.com

\begin{abstract}
ABSTRAK
Human Immunodeficiency Virus (HIV) yaitu virus yang dapat menyebabkan Aquired Immunodeficiency Syndrom (AIDS) dengan cara menyerang sel darah putih sehingga dapat merusak sistem kekebalan tubuh manusia. Penyebab kematian pada orang dengan HIV dan AIDS (ODHA) adalah penurunan sistem imunitas secara progresif sehingga infeksi oportunistik (IO) dapat muncul dan berakhir pada kematian. Sebagian besar remaja masih belum mengerti tentang bagaimana dampak yang akan ditimbulkan oleh pergaulan bebas dikalangan remaja yang terjadi saat ini, khususnya mahasiswa Akademi Kebidanan (AKBID) Tahirah Al Baeti yang merupakan gerbang kesehatan bagi masyarakat, sepatutnya mempunyai pengetahuan yang mumpuni tentang HIV dan AIDS sehingga mahasiswa AKTABE dapat dijadikan panutan dalam bersikap dan memberikan penjelasan tentang pengaruh negatif dari pergaulan bebas. Penelitian ini bertujuan untuk mengetahui pengetahuan dan sikap mahasiswa tingkat I dan II tentang HIV dan AIDS di AKBID Tahirah Al Baeti Bulukumba. Jenis penelitian ini menggunakan penelitian deskriptif dengan jumlah sampel sebanyak 44 responden. Teknik pengambilan sampel dengan accidental sampling. Instrument penelitian ini adalah lembar kuesioner. . Berdasarkan data kuesioner yang dibagikan ke mahasiswa tingkat I dan II AKBID Tahirah Al Baeti Bulukumba menunjukkan bahwa mahasiswa mempunyai pengetahuan yang cukup tentang HIV dan AIDS yaitu 59.1\%, sedangkan sikap mereka terhadap HIV dan AIDS ini juga berkategori cukup $(50.0 \%)$. Simpulan terhadap pengetahuan dan sikap yang dimiliki oleh mahasiswa Akademi kebidanan Tahirah Al Baeti Bulukumba Terhadap HIV dan AIDS berada dalam kategori cukup. Diharapkan penelitian kedepannya dapat mengambil sampel yang lebih besar dengan berbagai variabel.
\end{abstract}

Kata kunci: Mahasiswa, Pengetahuan, Sikap, HIV dan AIDS

\section{ABSTRACT}

Human Immunodeficiency Virus (HIV) is a virus that can cause AIDS by attacking white blood cells so that it can damage the human immune system. The cause of death in people with HIV and AIDS is a progressive decline in the immune system, which the opportunistic infections can appear and end to death. Most teenagers still do not understand how the impact that will be caused by promiscuity among adolescents is happening at this time, especially students of Tahirah Al Baeti Midwifery Academy which is a gateway for health community. This study aims to determine the knowledge and attitudes of the Tahirah Al Baeti Midwifery Academy students who are in level I and II about HIV and AIDS. This research used descriptive research with 44 students as research respondents. The research technique used accidental sampling. The research instrument was a questionnaire sheet. Based on the questionnaire data, it was found that the knowledge of the Tahirah Al Baeti Midwifery Academy students about HIV and AIDS was $59.1 \%$. While their attitudes towards HIV and AIDS was 50.0\%. We can concluded this research that knowledge and attitudes possessed the Tahirah Al Baeti Midwifery Academy 
students due to HIV and AIDS are in the sufficient category. We hope in future research can take a larger sample with various variables.

Keywords: Students, Knowledge, Attitudes, HIV, AIDS

\section{PENDAHULUAN}

HIV (Human Immunodeficiency Virus) yaitu virus yang dapat menyebabkan AIDS dengan cara menyerang sel darah putih yang dapat merusak sistem kekebalan tubuh manusia. Setelah beberapa tahun jumlah virus semakin banyak sehingga sistem kekebalan tubuh tidak lagi mampu melawan penyakit yang masuk. Virus HIV menyerang sel darah putih dan merubahnya menjadi tempat berkembang biak virus HIV, kemudian merusaknya sehingga tidak dapat digunakan lagi. Sel darah putih sangat di perlukan oleh tubuh maka ketika diserang penyakit tubuh kita tidak dapat memiliki pelindung.

Penyebab kematian pada orang dengan HIV dan AIDS (ODHA) adalah penurunan sistem imunitas secara progresif sehingga infeksi oportunistik (IO) dapat muncul dan berakhir pada kematian ${ }^{1}$. Data menunjukkan bahwa ada berbagai macam IO yang dapat menyertai HIV dan AIDS. Diantara berbagai penyakit infeksi tersebut, terdapat empat penyakit yang paling sering ditemukan pada pasien HIV dan AIDS, yaitu tuberkulosis, hepatitis, kandidiasis dan pneumonia ${ }^{2}$.

Pada tahun 2013, sebanyak 1,5 juta orang meninggal karena AIDS di seluruh dunia. Di Asia dan pasifik diperkirakan sekitar 4,8 juta orang yang hidup dengan HIV. Ahli kesehatan masyarakat di Indonesia menyatakan bahwa di Asia dan Pasifik jumlah infeksi HIV baru cenderung menurun sekitar $6 \%$, kecuali untuk wilayah Indonesia yang mengalami kenaikan sebanyak $48 \%{ }^{3}$.

Data statistik HIV dan AIDS di Indonesia tahun 2016 menujukkan bahwa jumlah total kasus HIV yaitu sebanyak 32.711 orang dan kasus AIDS sebanyak 7.864 orang. Berdasarkan faktor resiko nilai tertinggi dari jumlah kumulatif kasus AIDS banyak terjadi pada heteroseksual dari tahun 2009 sampai 2016 sebanyak 51.692 orang penderita. Pemerintah Indonesia menghadapi beberapa masalah dalam menentukan upaya penanggulangan khususnya masalah yang berhubungan dengan HIV dan AIDS ${ }^{4}$.
Berdasarkan angka kejadian HIV dan AIDS yang didapatkan dari dinas kesehatan Bulukumba pada tahun 2017 penderita HIV menurut kelompok umur 0-4 tahun tidak terdapat penderita dengan presentase $0 \%$, umur 5-14 tahun juga tidak terdapat penderita dengan presentase 0\%, umur 15-19 tahun tidak terdapat penderita dengan presentase $0 \%$, penderita dengan umur 20-24 tahun sebanyak 3 penderita dengan jenis kelamin perempuan sedangkan untuk penderita yang berjenis kelamin laki-laki tidak terdapat penderita HIV dengan presentase 20\%, umur 25-40 tahun pada tahapan umur ini terdapat banyak penderita HIV yaitu sebanyak 6 penderita berjenis kelamin perempuan dan 6 penderita yang berjenis kelamin laki-laki sehingga total penderita sebanyak 12 orang penderita dengan presentase $80 \%$ dan untuk umur $\geq 50$ tahun tidak terdapat penderita dengan presentase $0 \%$ sehingga total presentase keseluruhan umur sebanyak $100 \%$.

Sedangkan penderita AIDS menurut umur dan jenis kelamin kabupaten Bulukumba tahun 2017 untuk umur 0-4 tahun sebanyak 0 penderita dengan presentase $0 \%$, umur 5-14 tahun tidak terdapat penderita dengan presentase 0\%, untuk umur 15-19 juga tidak didapatkan penderita AIDS dengan presentase 0\%, penderita AIDS dengan umur 20-24 tahun dengan penderita yang berjenis kelamin perempuan terdapat 1 penderita sedangkan penderita yang berjenis kelamin laki-laki sebanyak $17 \%$, Adapun usia antara 25 sampai 40 tahun ditemukan yang menderita AIDS hanya yang berjenis kelamin laki-laki sebanyak 5 orang (83\%), sedangkan usia diatas 50 tahun tidak ditemukan penyakit AIDS ini. Alasan peneliti mengangkat judul tentang HIVdan AIDS pada mahasiswa karena pada saat melakukan pengambilan data awal peneliti memberikan beberapa pertanyaan singkat mengenai HIV dan AIDS kepada beberapa mahasiswa dan masih ada mahasiswa yang belum mengetahui faktor penyebab, cara penularan dan bahaya dari penyakit HIV dan AIDS tersebut. Berdasarkan hasil studi 
pendahuluan yang telah dilakukan pada tanggal 17 November 2018 di Akademi Kebidanan Tahirah Al Baeti Bulukumba. Data yang diperoleh bahwa jumlah mahasiswa tingkat 1 sebanyak 39 orang dan mahasiswa tingkat 2 sebanyak 24 orang.

\section{METODOLOGI}

\section{Jenis penelitian}

Jenis penelitian ini menggunakan penelitian deskriptif untuk mengetahui bagaimana pengetahuan dan sikap mahasiswa tentang HIV dan AIDS yang menggunakan data primer dimana semua data diperoleh dari hasil kuesioner yang telah diisi oleh mahasiswa Akademi Kebidanan Tahirah Al Baeti Kabupaten Bulukumba.

Populasi dan Sampel

a. Populasi

Populasi adalah keseluruhan obyek penelitian yang memiliki karakteristik tertentu yang ditetapkan oleh peneliti untuk dipelajari kemudian ditarik kesimpulannya. Populasi dalam penelitian ini adalah semua Mahasiswa Akademi Kebidanan Tahirah Al Baeti Bulukumba tingkat 1 dan 2 Sebanyak 44 Mahasiswa.

b. Sampel

Sampel adalah sebagian yang diambil dari keseluruhan objek yang diteliti dan dianggap mewakili seluruh populasi (Sastroasmoro 2014). sampel dalam penelitian ini adalah mahasiswa Akademi Kebidanan Tahirah Al Baeti Bulukumba tingkat 1 dan 2 berjumlah 44 Mahasiswa.

\section{Ruang Lingkup Penelitian}

Penelitian ini akan dilakukan pada tingkat 1 berjumlah 32 orang dan pada tingkat 2 berjumlah 12 orang, penelitian ini dilaksanakan di kampus Akademi Kebidanan Tahirah Al baeti Bulukumba mulai bulan Juni sampai Juli 2019 hal ini bertujuan untuk mengetahui pengetahuan dan sikap mahasiswa tentang HIV dan AIDS.

\section{Tekhnik Pengumpulan Data}

Pengumpulan data dilakukan dengan menggunakan kuesioner.

\section{Analisa Data ${ }^{5}$}

Dalam analisa data dideskripsikan angka atau nilai jumlah variabel dengan ukuran presentase dengan menggunakan rumus frekuensi presentase adalah

$$
\mathrm{P}=\frac{F}{N} \times 100 \%
$$

$$
\begin{aligned}
& \text { Keterangan: } \\
& \mathrm{F}: \text { Frekuensi } \\
& \mathrm{N}: \text { Banyaknya data } \\
& \mathrm{P}: \text { Angka presentas }
\end{aligned}
$$

\section{HASIL DAN PEMBAHASAN \\ HASIL}

Penelitian ini dilakukan di Akademi Kebidanan Tahirah Al Baeti Bulukumba selama 2 bulan mulai bulan Juni sampai Juli 2019. Pengumpulan data dilakukan dengan menggunakan kuesioner dan hasilnya diolah dalam bentuk tabel disertai penjelasan tabel.

1. Deskripsi Pengetahuan Mahasiswa Tentang HIV dan AIDS di Akbid Tahirah Al Baeti Bulukumba

Distribusi pengetahuan mahasiswa tentang HIV dan AIDS pada mahasiswa tingkat I dan II Akademi Kebidanan Tahirah Al Baeti Bulukumba disajikan pada table 1 di bawah ini.

Table 1. Distribusi frekuensi mahasiswa berdasarkan pengetahuan tentang HIV dan AIDS di Akbid Tahirah Al Baeti (AKTABE)

\begin{tabular}{ccc}
\hline Pengetahuan & Frekuensi & $\begin{array}{c}\text { Presentase } \\
(\%)\end{array}$ \\
\hline Baik & 14 & 31,8 \\
Cukup & 26 & 59,1 \\
Kurang & 4 & 9,1 \\
\hline Total & 44 & 100 \\
\hline
\end{tabular}

Sumber: Data primer pengetahuan HIV dan AIDS AKTABE (Rina., 2019)

Berdasarkan table 1 di atas dari 44 responden menunjukkan bahwa distribusi 
responden berdasarkan pengetahuan mahasiswa tentang HIV dan AIDS didapatkan 14 mahasiswa $(31,8 \%)$ yang berpengetahuan baik, dan $26(59,1 \%)$ yang berpengetahuan cukup, sedangkan 4 responden $(9,1 \%)$ yang berpengetahuan kurang.

\section{Deskripsi Sikap Mahasiswa Tentang HIV dan AIDS di Akbid Tahirah Al Baeti Bulukumba}

Distribusi sikap mahasiswa tentang HIV dan AIDS pada mahasiswa tingkat I dan II Akademi Kebidanan Tahirah Al Baeti Bulukumba disajikan pada table 2 di bawah ini.

Table 2. Distribusi frekuensi mahasiswa berdasarkan sikap tentang HIV dan AIDS di Akbid Tahirah Al Baeti (AKTABE)

\begin{tabular}{ccc}
\hline Sikap & Frekuensi & $\begin{array}{c}\text { Presentase } \\
(\%)\end{array}$ \\
\hline Baik & 18 & 40,9 \\
Cukup & 22 & 50,0 \\
Kurang & 4 & 9,1 \\
\hline Total & 44 & 100 \\
\hline
\end{tabular}

Sumber: Data primer sikap HIV dan AIDS AKTABE (Rina.,2019)

Pada tabel 2 dapat dilihat bahwa dari 44 responden ternyata mahasiswa yang bersikap baik terdapat 18 orang $(40,9 \%)$ dibandingkan dengan mahasiswa yang bersikap kurang yang hanya 4 orang $(9,1 \%)$. Akan tetapi yang bersikap cukup lebih banyak dibandingkan dengan mahasiswa yang mempunyai sikap baik dan kurang yaitu sebanyak 22 mahasiswa $(50,0 \%)$.

\section{PEMBAHASAN}

Penulis akan membahas dari hasil pengolahan data terkait deskripsi pengetahuan dan sikap mahasiswa Akbid Tahirah Al Baeti Bulukumba Tentang HIV dan AIDS. Berdasarkan hasil penelitian dan analisis variabel pengetahuan tentang HIV dan AIDS diketahui dari 44 responden ternyata mayoritas mahasiswa mempunyai pengetahuan yang cukup tentang HIV dan AIDS yaitu sebesar $59,1 \%$ dibandingkan dengan mahasiswa yang berpengetahuan baik yaitu $31,8 \%$. hal ini kemungkinan disebabkan oleh penegtahuan yang diperoleh dari pengalaman dan wawasan yang dimiliki oleh mahasiswa dikatakan cukup untuk memberikan tingkat pengetahuan yang dimiliki, apalagi yang dominan responden adalah mahasiswa tingkat I dengan jumlah 39 orang, yang mempunyai latar belakang wawasan dan pengalaman masih dibawah ratarata disbanding mahasiswa di tingkat lebih atas. Akan tetapi, tidak menutup kemungkinan diantara mahasiswa tingkat I juga mempunyai pengetahuan yang lebih dari cukup. Hasil penelitian memperlihatkan yang berpengetahuan cukup yaitu $88,6 \%$ lebih besar dibandingkan yang berpengetahuan baik. Sedangkan hasil yang didapatkan peneliti memperlihatkan dari 44 responden ternyata yang berpengetahuan cukup lebih besar 26 rsponden $(59,1 \%)$ dibandingkan dengan yang berpengetahuan baik yaitu 24 responden $\begin{array}{llll}(31,8 \%) \text {. Menurut Soekanto } & (2015)^{7}\end{array}$ pengetahuan atau kognitif merupakan domain yang sangat penting dalam membentuk tindakan seseorang (overt behaviour). Dari pengalaman dan penelitian terbukti bahwa perilaku yang didasari oleh pengetahuan akan lebih langgeng dari pada perilaku dan sikap yang tidak didasari oleh pengetahuan.

Sedangkan penelitian yang telah dilakukan dengan teori yang ada, peneliti menyimpulkan bahwa pengetahuan sangat berperan dalam sikap seseorang terhadap HIV dan AIDS, dimana semakin baik pengetahuan seseorang maka semakin besar kapasitas dalam bersikap baik terhadap sesuatu. Pada hasil penelitian ini memperlihatkan dari 44 responden, mahasiswa yang bersikap baik adalah 31,8\% lebih kecil dibanding yang bersikap cukup yang mempunyai presentasi $50 \%$. Hal ini bersesuain dan sejalan dengan penelitian Desi Chrismayanti (2016) yang memperlihatkan hasil dari 86 responden ternyata 64 responden $(50 \%)$ yang bersikap cukup. Menurut Notoatmodjo (2003) Sikap adalah merupakan reaksi atau respon seseorang yang masih tertutup terhadap suatu 
stimulus atau objek. Pembentukan sikap tidak lepas dari pengetahuan yang dimiliki, seseorang akan bersikap baik tergantung dengan kedalaman pengetahuan yang dimiliki dengan kurangnya pengetahuan responden tentang HIV dan AIDS sangat memungkinkan seseorang mempunyai sikap yang kurang terhadap HIV dan AIDS. Terbukti dari hasil penelitian ini memperlihatkan yang berpengetahuan cukup 26 responden $(59,1 \%)$ dan yang bersikap cukup 22 responden (50\%).

\section{Keterbatasan penelitian}

Penelitian ini dilakukan di Akademi kebidanan tahirah al baeti bulukumba ini tidak lepas dari keterbatasan atau penghambat. Instrument yang digunakan untuk mendapatkan data penelitian adalah instrument yang belum sempurna karena dbuat oleh peneliti sendiri berdasarkan tinjauan pustaka yang ada, mungkn masih ada aspek-aspek yang terlewatkan karena keterbatasan peneliti memahami konsep tersebut. Selain itu pengumpulan data melalaui kuesioner secara langsung oleh responden sehingga kualitas data yang dikumpulkan dalam penelitian sangat tergantung dari kemampuan dan kejujuran responden dalam menjawab setiap pertanyaan.

\section{KESIMPULAN}

Berdasarkan hasil penelitian terhadap 44 responden yang dilakukan di Akademi Kebidanan Tahirah Al Baeti Bulukumba Tentang Deskripsi Pengetahuan Dan Sikap Mahasiswa Akademi Kebidanan Tahirah Al Baeti Bulukumba tentang HIV dan AIDS dapat disimpulkan bahwa pengetahuan mahasiswa tentang HIV dan AIDS masih setaraf cukup yaitu 59,1\% disbanding dengan berpengetahuan baik $(31.8 \%)$ dan kurang ( 9,1\%). Sedangkan sikap yang ditunjukkan mahasiswa terhadap HIV dan AIDS tergolong cukup yaitu (50\%) dibandingkan dengan sikap baik $(40,9 \%)$ dan kurang $(9,1 \%)$ yang ditunjukkan mahasiswa tingkat I maupun II Akademi Kebidanan Tahirah Al Baeti Bulukumba.

\section{DAFTAR PUSTAKA}

1. Depkes RI. 2006. Pedoman Penyelenggaraan dan Prosedur Rekam Medis Rumah Sakit di Indonesia. Jakarta.

2. WHO. HIV DAN AIDS (internet). C2013 (cited 2013 November 20). Available from

http://www.who.int/topics/hiv_aids/en/. Diakses tanggal 15 November 2018.

3. Najmah. 2016. Epidemiologi Penyakit Menular. Jakarta: CV Trans Info Media.Diakses 15 November 2018.

4. Ditjen PP dan PL Kemenkes RI. 2016. Statistik Kasus HIV DAN AIDS di Indonesia. Jakarta.

5. Sastroasmoro, Sudigdo. 2014. Dasardasar metodologi penelitian klinis. tahun 2014.

6. Sugiyono. 2007. Metode Penelitian Kuantitatif Kualitatif dan $R \& D$. Bandung. Alfabeta.

7. Soekanto. (2015). Definisi Pengetahuan. http://www.definisi dan pengetahuan. com. Diakses tanggal 23 November 2018 